\title{
Students' School-Based Assessment Scores Relationship with Students' Readiness, Motivation, and National Examination Scores of Mathematics Subject
}

\author{
Furintasari Setya Astuti \\ Heri Retnawati \\ Universitas Negeri Yogyakarta \\ furintasari.sa@gmail.com
}

\begin{abstract}
The aim of this current research was to know the relationship between students' scores from the school-based assessment and their readiness, motivation, and national examination scores. The method of this research was survey. The study involved 364 students from some of senior high schools in Ngawi. The data were analyzed using path analysis. There were four students who were considered outliers and should therefore be excluded in the study, resulting in the final data from 360 students. The results of this research showed that there was a direct relationship between students' scores from the school-based assessment with students' motivation and their scores in national examination, but there was no relationship between the school-based scores with students' readiness. In addition, there was an indirect relationship between motivation and school-based scores with readiness. The research also indicated that there was a negative correlation between school-based scores with readiness, motivation, and students' scores in the national examination in mathematics.
\end{abstract}

Keywords: motivation, national examination, path analysis, readiness, school-based assessment

\begin{abstract}
Abstrak: Tujuan dari penelitian ini untuk mengetahui hubungan nilai sekolah dengan kesiapan, motivasi, dan nilai ujian nasional. Metode yang digunakan adalah survey. Sampel penelitian adalah siswa dari beberapa SMA di Kabupaten Ngawi yang berjumlah 364 siswa. Teknik analisis data yang digunakan adalah analisis jalur (path analysis). Setelah dilakukan uji prasyarat terdapat empat data yang merupakan outlier dan harus dibuang, sehingga sampel akhir sebesar 360 siswa. Hasil penelitian ini adalah terdapat hubungan langsung antara nilai sekolah dengan motivasi dan nilai ujian nasional matematika tetapi tidak terdapat hubungan antara nilai sekolah dengan kesiapan. Selain itu terdapat hubungan tidak langsung antara motivasi dengan nilai ujian nasional dengan perantara kesiapan. Dalam penelitian ini juga menational examination scorejukkan bahwa terdapat korelasi negatif antara nilai sekolah dengan kesiapan, motivasi, dan nilai ujian nasional matematika siswa.
\end{abstract}

Kata kunci: analisis jalur, kesiapan, motivasi, nilai sekolah, ujian nasional

For the sake of the education quality, the government has attempted to realize the improvement through numerous ways such as facilities and infrastructure improvement, teaching material development and procurement, teachers and education personnel training, and curriculum and evalation improvement as the most vital and paramount elements. According to Minister of Education and Culture Decree No. 66 of 2013, students' learning outcomes in elementary and middle school are measured in accordance with education evaluation standard which is applied in national level. In this case, the evaluation is in the form of national examination. National examination takes a role as an evaluation mean on students at the end of their study in school. According to Minister of Education and Culture Decree No. 5 of 2015 Article 21 Paragraph 1, the results of national examination are used for clustering program quality and/or educational unit, considering the selection on the next degree of education, considering in giving further educational edvice, and providing assistance and aid in order to improve the quality of education.

National examination takes a strategic role in education quality management. Final examination of educational unit serves as paramount strategy to improve education quality which is widely applied 
and implemented by developing countries with limited resources. Well-planned and well-conducted national examination will be able to provide useful information for conducting and accelarating quality of education continously. However, the presence of national examination provides a room for a debates within the society. During national examination, students are asked to answer a multiple choices questions. Multiple choices question is effective to measure learning and teaching achievement and it is able to cover the entire topic of a subject (Aziz \& Sugiman, 2015). Therefore, eventhough national examinaton sparks off debate, the presence of national examination since 2003 is still conducted by government at the end of the study in school.

Government policy on graduation standard is changing every single year. It indeed aims at generating a qualified and proficient human resources. Government policy on graduation standrad, particularly national examination criteria in 2013-2014, has changed. In which, the criteria of national examination is higher than before to demand higher students' readiness and learning motivation. Before 2015, the results of national examination serve as one of the requirement of students' graduation. However, beginning in 2016, the results of national examination is no longer served as students' graduation requirement.

Before taking national examination, students are required to prepare themself, both material readiness and psychological condition. Material readines is important to be taken into account during learning process of Mathematics subject. In fact, students encountered learning delays.

Twelfth graders' learning readiness is deficient since students consider that national examination will not be conducted in the near future. During the learning activity in the classroom, most students encountered obstacles because of learning readiness lackness. According to Baden and Major (2004:27), Piaget believed that the actvities learners could complete mathced their cognitive stage or readiness. Thus, readiness highly influences cognitive aspect of students, in particular the results of national examination. Furthermore, Morisson and Fletcher (2002:3) opine that Cognitive Readiness is a mental preparation (including skills, knowledge, abilities, motivations, and personal dispositions) an individual needs to establish and sustain competent performance in the complex and unpredictable environment.

In addition to readiness, during the preparation of national examination, students indeed need a high learning motivation. Strong motivation within student will encourage interest, willingness, and passion during learning process (Trisnawati \& Wutsqa, 2015).

Learning motivation is one of the characteristics which is able to influence affective aspect of students. Motivation has positive impact upon learning; stimulates, sustains and give directions to an activity. Highly motivated students often require little guidance from the teachers and are capable of doing many higher degree of complicated work independently (Mubeen, Saeed, \& Arif, 2013: 81).

Students with higher motivation are able to handle and solve complicated problems independently with minimum assistance from the teacher. Motivation is defined as internal and external encouragement (Elliot, 2000; Evans, 1999), passion, attempt, and persistance of individual to create a behavioral changing in order to achieve certain goal (Schunk, Pintrich, \& Meece, 2010; Wolkfolk, 2007; Santrock, 2014; Elliot, 2005; Ormrod, 2003).

Motivation includes intrinsic and extrinsic motivation. Intrinsic motivation is a motivation that naturally comes from within an individual which is driven by the individual's interest or pleasure (Wolkfolk \& Margetts, 2007; Miller, 2009). Meanwhile, extrinsic motivation is a motivation based on factors other than within the individual such as the way teacher teaches, the influence of learning groups, enjoyable and innovative learning process and rewards or punishment (Wolkfolk, 2007; Santrock, 2014; Amri \& Abadi , 2013; Farhan \& Retnawati, 2014). According to Santrock (2014), intrinsic motivation has a positive correlation with the score obtained by students. Therefore motivation is very important in order to achieve the goal of learning. There is a significant correlation between achievement and motivation (Sikhawari, 2012, Widyastuti, 2010).

The aforementioned explanation indicates that there are some variables which theoretically correlate with the results of national examination. It is important to know and understand whether the variable of school-based assessment score correlates with other variables which are related with national examination (readiness, motivation, and the score of national examination). In this paper, the authors focused on the correlation of the above-mentioned variables. 


\section{METHOD}

This research employed survey technique with descriptive quantitative approach. This research, data measurement was directly conducted on the students' readiness and motivation of Senior High School around Ngawi Regency.

The population of this research is the entire Twelfth graders of Senior High School in Ngawi Regency Academic Year 2015/2016 which consisted of 13 Senior High School and six Madrasah Aliyah with 2637 students. Meanwhile, the sample of this research took 364 students from six schools.

This research was conducted from March to May 2016. Stratified random sampling technique was used to obtain research samples by categorizing school in accordance with the results of national examination on Mathematics subject of Academic Year 2014/2015. At the end, it obtained six schools as research samples which consisted of SMAN 1 Kwadungan, SMAN 1 Karangjati, SMAN 1 Ngawi, MAN Ngawi, MAN Paron, and MAN Tempursari with 364 studentd proportionally.

The research variables are school-based assessment score, readiness, motivation, and the results of national examination on Mathematics subject. School-based assessment score is a collection of the student' raport average score in the third until fifth semester with school-based examination. The percentage of raport score is $30 \%$ to $70 \%$, school-based examination takes $30 \%$ to $50 \%$. Meanwhile, the percentage of national examination score is $100 \%$.

Readiness is an individual condition which can be influenced by the level of maturity, knowledge, and skills in order to achieve expectations of learning. In this study, the readiness of students is defined as the state of students related to knowledge (material) as a form of maturity in facing national examinations. Motivation is an internal and external drive, enthusiasm, effort, and persistence within an individual to create behavioral changing in order to achieve certain goals. The national exam score on Mathematics subject is the pure score that learners obtained.

This research utilized readiness test in the form of multiple choice with 40 items for both Natural Science and Social Studies classes as the instrument. In addition, as for non-test instrument, this research utilized questionnaire on students motivation. It consisted of 25 items of question. As for schoolbased assessment scores and national examination score, it were obtained from school archive.

Content validation was conducted to prove test instrument validity as well as the motivation questionnaire. While construct validity was used to affirm the validity of questionnaire. To determine the index of validity, it used aiken validity index with the following formula:

$$
V=\frac{\sum_{i=1}^{n} s_{i}}{n(c-1)}
$$

Remarks:

$n$ : Validator(s)

$c:$ The number of category choose by the validator(s)

$s_{i}$ : Score determined by the $i$ validator ke $i$ reduced by

$s_{i}$ the lowest category score

According to Retnawati (2015:43), if the V index is less than 0.4 , then its validity is low. If the $\mathrm{V}$ index is $0.4-0.8$, then its validity is moderate. And if the $\mathrm{V}$ index is higher than 0.8 , then its validity is high. Based on validators judgment, the index of aiken validity obtained 0.84 for the readiness test of both Natural Science and Social Studies classes, while for motivation questionnaire obtained 0,91 . Therefore, it can be said that the test instrument items and questionnaire have meet the validity standard. Furthermore, to prove the validity of the contents of the instrument, it used categorization of Azwar (2010: 163) which is presented in Table 1.

\section{Table 1. Data Conversion from Quanti-} tative to Qualitative

\begin{tabular}{ll}
\hline Score Interval & $\begin{array}{l}\text { Category } \\
x_{i}+1,5 S b_{i}<x\end{array}$ \\
\hline$x_{i}+0,5 S b_{i}<x \leq x_{i}+1,5 S b_{i}$ & Very High \\
\hline$x_{i}-0,5 S b_{i}<x \leq x_{i}+0,5 S b_{i}$ & Moderate \\
\hline$x_{i}-1,5 S b_{i}<x \leq x_{i}+0,5 S b_{i}$ & LoW \\
\hline$x \leq x_{i}-1,5 S b_{i}$ & Very Low \\
\hline
\end{tabular}

Remarks:

$x$ : actual score

$x_{i}$ : average ideal score $\frac{1}{2}$ (maximum score+ minimum score)

$S b_{i}$ : ideal standard deviation: $\frac{1}{6}$ (maximum score+ minimum score).

Maximum score : items $\mathrm{x}$ higher score. 
Minimum score : items x lower score.

On the validation sheet of the questionnaire instrument there are 25 points of the assessed statements, the highest score of each item is 5 and the lowest score is 1 , then the maximum score is $25 \times 5=125$ and the lowest score $25 \times 1=25$. The ideal score $(x)$ is $(125+25)=75$ and ideal standard deviation $(125-25)=16.67$. By using the formula of conversion in table 1 , it obtained categorization table of validity of the contents of the questionnaire instruments as shown in Table 2.

\section{Table 2. Categorization of Motivation Questionnaire Content Validity}

\begin{tabular}{ll}
\hline Interval & Criteria \\
\hline$x>100$ & Very High \\
\hline $83,3<x \leq 100$ & High \\
\hline $66,7<x \leq 83,3$ & Fairly High \\
\hline $50<x \leq 66,7$ & Low \\
\hline$x \leq 50$ & Very Low \\
\hline
\end{tabular}

The motivation questionnaire instrument is considered valid if the expert judgment meets the qualitative classification is at least high $(\mathrm{x}>83.3)$. Based on the validation results from the experts, it obtained a score of 116.7 , so it can be concluded that the motivation questionnaire instrument is said to be valid.

On the validation sheet of the readiness test instrument of both Natural Science and Social Studies programs each have 40 items assessed, the highest score of each item is 5 and the lowest score is 1 , then the maximum score obtained is $40 \times 5=$ 200 and the lowest score obtained is $40 \times 1=40$. The ideal mean score $(x)$ is $1 / 2(200+40)=120$ and the ideal standard deviation (SD) is $1 / 6(200-40)=26.67$.

By using conversion formula on Table 1, it obtained categorization table of validity of the contents of the questionnaire instruments as shown in Table 3.

Table 3. Categorization of Readiness Test Content Validity

\begin{tabular}{ll}
\hline Interval & Criteria \\
\hline$x>160$ & Very High \\
\hline $133,3<x \leq 160$ & High \\
\hline $106,7<x \leq 133,3$ & Fairly High \\
\hline
\end{tabular}

\begin{tabular}{ll}
\hline Interval & Criteria \\
\hline $80<x \leq 106,7$ & Low \\
\hline$x \leq 80$ & Very Low
\end{tabular}

The motivation questionnaire instrument is considered valid if the validators assessment meets the qualitative classification is at least high $(\mathrm{x}>$ 133.3).

Based on the results of validation from the expert, it obtained a score of 173.7 , so it can be concluded that the readiness test instrument is said to be valid. Based on the validity of the exploratory constructs concluded that the motivation questionnaire is valid. Reliability of readiness test using KR-20 formula. The formula of KR-20 is as follows:

$$
K R 20=\left[\frac{N}{N-1}\right]\left[\frac{\sigma_{t}^{2}-\sum_{i=1}^{N} p_{i}\left(1-p_{i}\right)}{\sigma_{t}^{2}}\right]
$$

(Allen \& Yen, 1979).

Remarks:

KR20: Instrument reliability coefficient

$N$ : number of instrument items

$\sigma_{t}^{2}:$ total score variance

$p_{i}$ : the proportion of subjects who answered correctly on an item.

By utilizing Microsoft Excel, it obtained a reliability coefficient of 0.80 for both Natural Science and Social Studies programs. Meanwhile, for questionnaire motivation, it used Conbrach alpha formula with the following formula:

$\alpha=\left[\frac{N}{N-1}\right]\left[\frac{\sigma_{t}^{2}-\sum_{i=1}^{N} \sigma_{i}^{2}}{\sigma_{t}^{2}}\right]$

$\alpha$ : instrument reliability coefficient

$N$ : number of instrument items.

$\sigma_{t}^{2}:$ total score variance

$\sum_{i=1}^{N} \sigma_{i}^{2}$ : the number of variance of the instrument

By employing SPSS 20.0, it obtained reliability coefficient of 0.80 . Due to the reliability coefficient of readiness test and motivation questionnaire which is more than 0.6 , it can be said that the instrument of readiness test and motivation questionnaire is reliable.

Data analysis techniques were used to analyze data and to test research hypotheses. The data to be analyzed were school-based assessment score data, readiness test result, motivation questionnaire result, and national examination of Mathematics test score. Before performing hypothesis test, assumption test such as normality test, multicollinearity test, 
hetero-skedasticity test, and autocorrelation test were conducted.

Outlier tests were used to detect the presence or absence of the data. To detect outlier, it used blox test plot with SPSS 20.0. After testing, there are four data that is the outlier of data to $67,76,104$, and 106 so that these four data must be discarded.

Normality test was performed by using Komogorov-Smirnov test. The decision criteria used is normal distributed data if the significance value is greater than 0.05 . Based on data analysis using SPSS 20.0 the results obtained are presented in Table 4.

Table 4. Normality Testing

\begin{tabular}{llll}
\hline Readiness & Motivation & SS & NES \\
\hline sig 0,085 & 0,083 & 0,102 & 0,053 \\
\hline
\end{tabular}

From Table 4, it is found that the significance value of each variable is more than 0,05 , so it can be concluded that the data is normally distributed. The multicollinearity test is used to test whether there is a linear relationship between variables. If the tolerance value is more than 0.1 , the value of variance inflation factor (VIF) is less than 10 , and there is no correlation between the variables whose value is more than $95 \%$ then it can be concluded that there is no multicollinearity. By using SPSS 20.0 the results obtained are presented in Table 5.

Table 5. Multicollinearity Testing

\begin{tabular}{lllll}
\hline & Readiness & $\begin{array}{l}\text { Motiva- } \\
\text { tion }\end{array}$ & SS & NES \\
\hline Tolerance & 0,378 & 0,367 & 0,962 & 0,209 \\
\hline VIF & 2,644 & 2,722 & 1,040 & 4,775 \\
\hline
\end{tabular}

From Table 5 it is found that the tolerance value of each variable is more than 0.1 and the VIF value of each variable is less than 10 . Further, it will identify the correlation coefficient of each variable. By employing SPSS 20.0 the results obtained are presented in Table 6 .
Tabel 6. Correlation Coefficient Test

\begin{tabular}{lllll}
\hline Aspect & NES & SS & $\begin{array}{l}\text { Readi- } \\
\text { ness }\end{array}$ & $\begin{array}{l}\text { Moti- } \\
\text { vation }\end{array}$ \\
\hline NES & 1,000 & 0,140 & $-0,659$ & $-0,664$ \\
\hline SS & 0,140 & 1,000 & $-0,122$ & $-0,003$ \\
\hline Readiness & $-0,659$ & $-0,122$ & 1,000 & 0,114 \\
\hline Motivation & $-0,664$ & $-0,003$ & 0,114 & 1,000 \\
\hline
\end{tabular}

From Table 6 it is found that the highest correlation coefficient is -0.664 or about $66.4 \%$. Therefore, this correlation is still below 95\%. From table 2 and table.. it can be concluded that the tolerance value of each variable is more than 0.1 , the VIF value of each variable is less than 10 , and the correlation of each variable is below $95 \%$. This means there is no multicollinearity.

Hypothesis test was used to know the existence of relationship between school value with readiness, motivation, and value of national exam mathematics subject. Test the hypothesis using path analysis by employing LISREL program. The hypothesis in this study is as follows: Ho: There is no relationship between school-based assessment score with readiness, motivation, and national examination score of Mathematics subject H1: There is relationship between school-based assessment score with readiness, motivation, and national.

The decision criteria of the hypothesis $\mathrm{Ho}$ is rejected if the chi-square is small, $p$-value $\geq 0.05$, and RMSEA $\leq 0.08$.

\section{RESULTS AND DISCUSSION}

\section{Results}

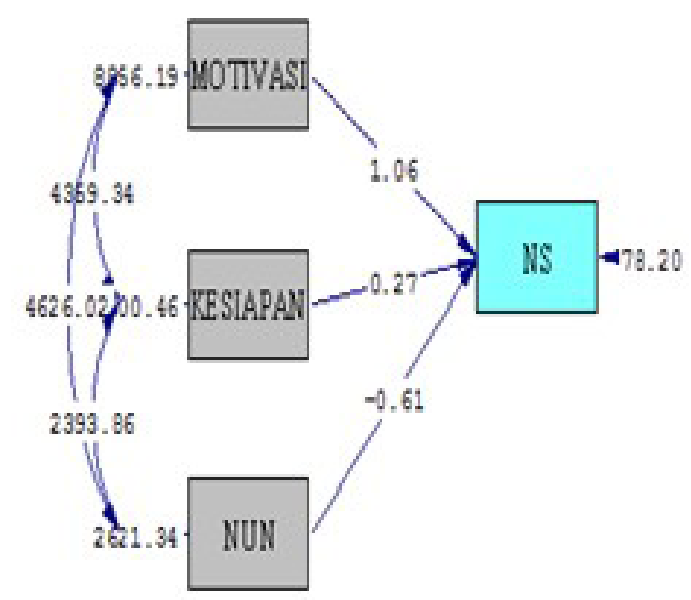

Figure 1. Initial Path Analysis (Standardized) 
From the output in Figure 1, it shows that the chi-square value of $358.08, p$-value $=0,000$ and RMSEA $=0.499$. Because the value of chi-square is very large, $p$-value $\leq 0.05$ and RMSEA $\geq 0.08$, it can be concluded that the path is not fit or Ho is accepted. Due to the path that does not fit, therefore modified path should be taken.

Based on the LISREL result, there is a red path coefficient, this means the path must be changed. By employing LISREL, it obtained path modification as in Figure 2.

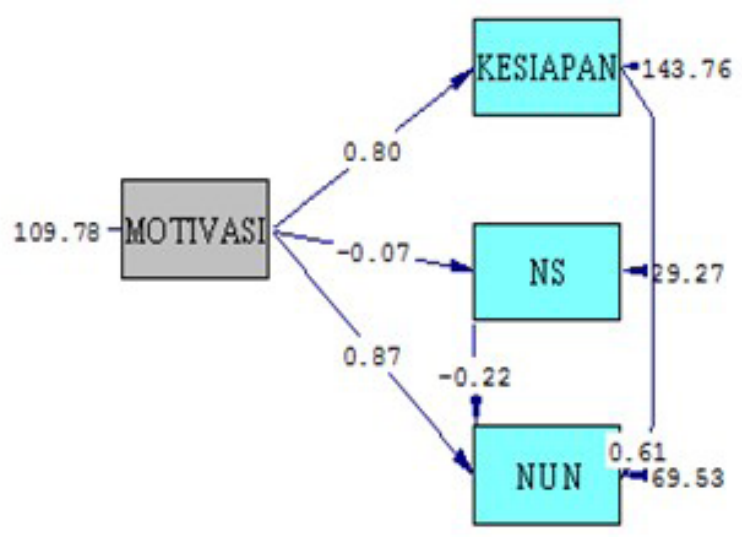

Figure 2. Modification Path

By employing LISREL, it obtained chi-square value of 0.56 , p-value value of 0.4526 , and RMSEA value of 0.000 . Due to the small chi-square value, $\mathrm{p}$-value $\geq 0.05$ and RMSEA $\leq 0.08$ then the modified path is also fit. Then it will be seen based on t-value.

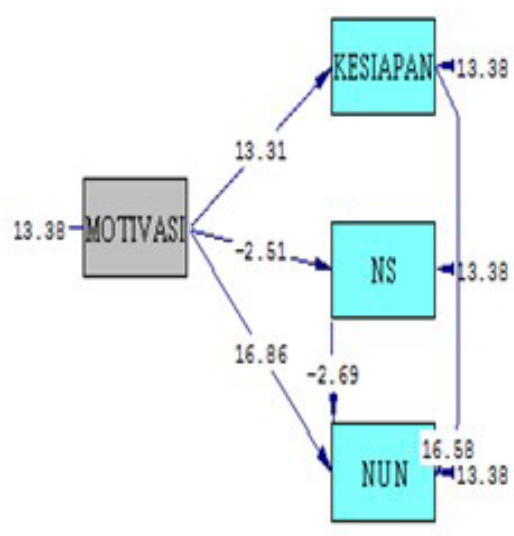

Chi-Square $=0.56$, df $=1$, p-value $=0.45626$, RMSEA $=0.000$

Figure 3. T-value of Modification Path

According to the LISREL results based on $\mathrm{t}$-value, there is no red path coefficient. This path is already fit. In addition, the model with data is also supported by Goodness of Fit Index $(\mathrm{GFI})=1.00$, Adjusted Goodness of Fit Index (AGFI) $=1.00$, Comparative Fit Index $(\mathrm{CFI})=1.00$, and Normed Fit Index $(\mathrm{NFI})=1,000$. According to Schumacker \& Lomax (2004: 82) if GFI, AGFI, CFI, NFI have values greater than 0.9 then the suitability of the model is said to be good. Table 7 is the LISREL output criteria and results.

Table 7. Goodness of Fit Index

\begin{tabular}{llll}
\hline & Cut of value & $\begin{array}{l}\text { LISREL } \\
\text { Results }\end{array}$ & Note \\
\hline $\begin{array}{l}\text { Chi- } \\
\text { square }\end{array}$ & $\begin{array}{l}\text { Expected } \\
\text { to be small }\end{array}$ & 0,56 & Good \\
\hline$p$-value & $\geq 0,05$ & 0,456 & Good \\
\hline RMSEA & $\leq 0,08$ & 0,000 & Good \\
\hline GFI & $\geq 0,9$ & 1,000 & Good \\
\hline AGFI & $\geq 0,9$ & 1,000 & Good \\
\hline CFI & $\geq 0,9$ & 1,000 & Good \\
\hline NFI & $\geq 0,9$ & 1,000 & Good \\
\hline
\end{tabular}

After knowing that the data was fit, then it will be continued to analyze the relationship between variables. By utilizing LISREL, it obtained the output as in Table 8.

Table 8. Endogenous Variable Correlation

\begin{tabular}{|c|c|c|c|}
\hline & Readiness & NES & SS \\
\hline Reasiness & - & - & - \\
\hline NES & $\begin{array}{c}0,61 \\
(0,04) \\
16,58\end{array}$ & - & $\begin{array}{l}-0,22 \\
(0,08) \\
-2,69\end{array}$ \\
\hline SS & - & - & - \\
\hline
\end{tabular}

Based on Table 8 , it shows that there is a relationship between readiness with National Examination Score with path coefficient of 0.61 and $\mathrm{t}$-value of 16.58. In addition, there is also relationship between School-based assessment score with National examination score with path coefficient of -0.22 with t-value of -2.69 . The LISREL program also displays outputs to show the relationship between exogenous variables and endogenous variables. Table 9 is the output of the LISREL program. 
Table 9. Path Coefficient between Exogenous and Endogenous Variable

\begin{tabular}{cc}
\hline & Motivation \\
\hline \multirow{2}{*}{ Readiness } & 0,80 \\
& $(0,06)$ \\
& 13,31 \\
\hline \multirow{2}{*}{ NES } & 0,87 \\
& $(0,05)$ \\
& 16,86 \\
\hline \multirow{2}{*}{ SS } & $-0,07$ \\
& $(0,03)$ \\
& $-2,51$ \\
\hline
\end{tabular}

From Table 9, it shows that there is a relationship between motivation with readiness with path coefficient of 0.80 and t-value of 13.31 . There is also a relationship between motivation with national examination score with path coefficient of 0.87 and t-value of 16.86. In addition there is also a relationship between motivation with the schoolbased assessment with the coefficient of the path of -0.07 and $t$-value of-2.51. Table 9 also shows that motivation has a direct relationship with readiness, national examination score, and school-based assessment score. This is in accordance with research conducted by Sikhawari (2014) \& Widyastuti (2010) which concludes that there is a significant correlation between motivation and achievement in this case is readiness and national examination score. Readiness test is a matter of national test trials with indicators in accordance with the indicators issued by BNSP 2016. To show an indirect relationship, LISREL also provides an output as in Table 10.

Table 10. Indirect Relationship of Variables

\begin{tabular}{cc}
\hline & Motivation \\
\hline Readiness & - \\
\hline & 0,51 \\
NES & $(0,05)$ \\
& 10,54 \\
\hline SS & - \\
\hline
\end{tabular}

Table 10 shows that there is an indirect relationship between motivation and national examination score. Based on the path that has been obtained, before having a relationship with national examination score, the previous motivation has a relationship with readiness. In other words motivation has a relationship with national examination score intermediated by readiness. This is in accordance with research conducted by Rotgans \& Schmidt (2012) which concludes that there is a relationship between motivation with achievement in this case is national examination score because national examination score is a measurement of student achievement which is done nationally, but the relationship is an indirect relationship.

\section{Discussions}

Based on the result of the modification path, it can be concluded that there is a correlation between school-based assessment with motivation and the national examination, but there is no relation between school-based assessment and readiness. Furthermore, there is also a relationship between readiness with motivation, there is a relationship between the national examination with motivation and readiness.

In addition to looking at the path, this study also looked at the correlation between school-based assessment score with motivation and readiness and national examination score of Mathematics subject. Table 11 is the result of the correlation calculation.

Table 11. Correlation

\begin{tabular}{ll}
\hline & SS \\
\hline Readiness & $-0,04387$ \\
\hline Motivation & $-0,13167$ \\
\hline NES & $-0,15308$ \\
\hline
\end{tabular}

From Table 11, it can be seen that the schoolbased assessment score has a negative correlation with the readiness, motivation, and the national exam score, but the correlation is a weak correlation because the correlation coefficient value tends to approach 0 . This means that the higher the readiness, motivation, and the national exam score of Mathematics subject, the lower the school value. To support the results of this study, the frequency polygons is presented in Figure 4. 


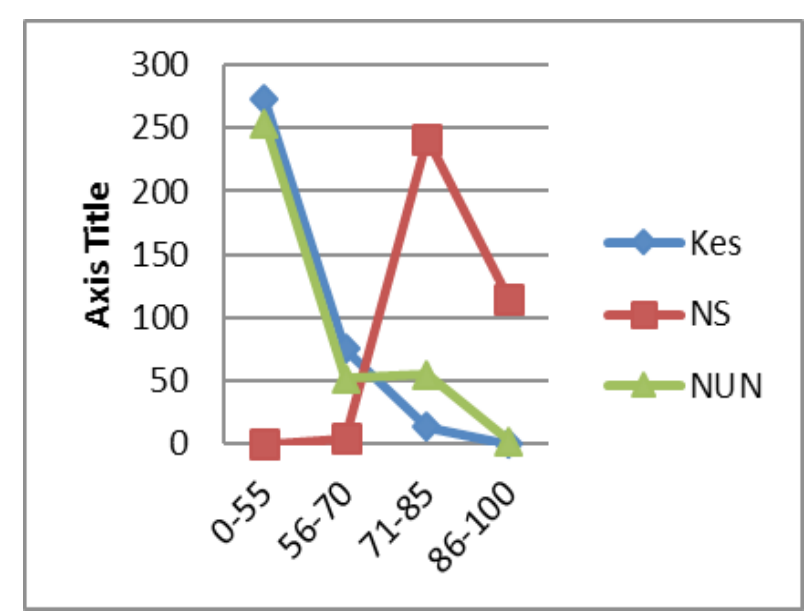

Figure 4. Frequency Polygon

From Figure 4, it can be seen that the largest number of students on the readiness variable and national examination score lies in the value $0-55$ or can be said to be low. In contrast, the highest number of students in the school-based assessment score variables lies in the 71 to 85 or high. This negative correlation is due to the difference in the measuring instruments that are given to students in different schools. Each school has the authority to make different school exam questions and the indicators of questions is not all in line with the national examination or any readiness test. This is what causes a negative correlation between readiness, motivation, national examination score, and schoolbased assessment score.

After knowing the data distribution of each variable, it will be seen the average of each variable as shown in Table 12.

Table 12. Each Variable Average Results

\begin{tabular}{lllll}
\hline Readness & \multicolumn{3}{l}{ MotivivationSS } & NES \\
\hline Avg & 45,668 & 93,5222 & 82,884 & 47,847 \\
\hline
\end{tabular}

From table 12 it can be seen that the average readiness and scores of national exam students are under 55 or are in low category. While the motivation and value of schools are in high category.

\section{CONCLUSION AND SUGGESTIONS}

According to the results and discussion above, this research concludes that there is a direct correlation between school-based assessment with motivation and national exam score, but there is no relation between school-based assessment and readiness. There is also an indirect relationship between motivation and test scores through the intermediate of readiness variable. In addition, in this study also found the fact that there is a negative correlation between the school-based assessment with the readiness, motivation, and national examinations. The average readiness and national examination of students are in the low category whereas the motivation and the school-based assessment are in high category.

The average readiness and and the national exam score are below 55 or are in the low category, so it is advisable for the teacher or the school to apply methods of learning that can train students' reasoning. Students are not only sharpened related problems with the level of understanding and application only but also be exposed with the problem through reasoning ability.

For future research, it is better to conduct case studies on students with the highest readiness, motivation, school-based assessment score, and the national examination score scores in order to explore directly the unique things that might be occured and to clearly know the cause of the high or low score of students. Future research is suggested to extend the population coverage of the residency of Madiun in order to see the wider influence of national exam policy related to the passing reference so that it can be an evaluation for the authorities in determining the national exam policy.

\section{REFERENCES}

Allen, M. J. \& Yen, W. M. 1979. Introduction to Measurement Theory. California, CA: Wadsworth, Inc.

Amri, M. S., \& Abadi, A. M. 2013. Effect of PMR with IGT to Motivation, Attitude, and Problem Solving Skills Geometry Class VII. Pythagoras. Journal of Mathematics Education, 8(1): 55-68.

Aziz, \& Sugiman. 2015. Analysis of Cognitive Difficulties and Affective Problems High School Students in Learning Math National Exams. Mathematics Education Research Journal, 2(2): 162-174.

Azwar, S. 2010. Metode Penelitian. Yogyakarta: Pustaka Pelajar.

Baden, M. S., \& Major, C. H. 2004. Foundations of Problem-Based Learning. Oxford: Open University Press.

Elliot, J. G, et al. 2005. Motivation, Engagement, and Educational Performance. New York, NY: Palgrave Macmillan.

Elliot, S. N., Kratochwill, T. R., \& Cook, J. L. 2000. Educational Psychology; Effective Teaching, Effective Learning (3rded). Boston: Mc Graw Hill. 
Evans, L. 1999. Managing to Motivate: A Guide for School Leaders. London: Casell.

Farhan, M., \& Retnawati, H. 2014. The Effectiveness of PBL and IBL in Terms of Student Achievement, the Ability of a Mathematical Representation, and Motivation to Learn. Mathematics Education Research Journal, 1(2): 227-240.

Miller, M. D. 2009. Measurement and Assessment in Teaching. New Jersey: The Lehigh Press, Inc.

Morrison, J. E., \& Fletcher, J. D. 2002. Cognitive Readiness. Alexandria: Institute For Defense Analysis.

Mubeen, S., Saeed, S., \& Arif, M. H. 2013.An Investigaton the Gender Difference into the Status of Intrinsic Motivation Towards Learning Science Among Intermediate Science Students. Journal of Humanities and Social Sience, 10(6): 81-85.

Ormrod, J. E. 2003. Educational Psycology Developing Learners (4rd ed.). New Jersey, NJ: Pearson Education.

Permendikbud. 2013. Peraturan Menteri Pendidikan dan Kebudayaan RI Nomor 66 Tahun 2013, tentang Standar Penilaian Pendidikan. Jakarta

Permendikbud. 2015. Peraturan Menteri Pendidikan dan Kebudayaan RI Nomor 5 Tahun 2015, tentang Kriteria Kelulusan Peserta Didik, Penyelenggaraan Ujian Nasional dan Penyelenggaraan Ujian Sekolah/Madrasah/Pendidikan Kesetaraan Pada SMP/MTs atau yang Sederajat dan SMA/MA/SMK atau yang Sederajat. Jakarta.

Retnawati, H. 2015. Analisis Kuantitatif Instrumen Penelitian. Yogyakarta:Parama.
Rotgans, J. I., \& Schmidt, H. G. 2012. The Intricate Relationship Between Motivation and Achievement: Examining the Mediating Role of SelfRegulated Learning andAchievement-Related Classroom Behaviors. International Journal of Teaching and Learning in Higher Education, 24(2): 197-208.

Santrock, John W. 2010. Educational Psychology. Terjemahan oleh Harya Bhimasena. 2014. Jakarta: Salemba Humanika

Schumacker, R. E. \& Lomax, R. G. 2004. A Beginners's Guide to Structural Equation Modeling $2^{\text {nd }}$ Edition. NJ: Lawrence Erlbaum.

Schunk, D. H., Pintrich, P. R., Meece, J.L. 2010. Motivation in Education: Theory, Research, and Applications. Upper Saddle River, NJ: Pearson Education

Sikhawari, T. D. 2014. A Study of the Relationship Between Motivation, Self-Concept and Academic Achievement of Students at a University in Limpopo Province, South Africa. Journal of Educational Science, 6: 19-25.

Trisnawati \& Wutsqa, D. U. 2015. Perbandingan Keefektifan Quantum Teaching dan TGT pada PembelajaranMatematika ditinja $\mathrm{u}_{\text {dariPrestasidan }}$ Motivasi. Jurnal Riset Pendidikan Matematika, 2(2): $297-307$

Widyastuti, R. 2010. Hubungan Motivasi Belajar dan Hasil Tes Intelegensi dengan Prestasi Belajar. Tesis tidak diterbitkan, Surakarta: Universitas Sebelas Maret.

Wolkfolk, A., \& Margaretts. 2007. Educational Psychology. Boston: Allyn \& Bacon 